Tropical Journal of Pharmaceutical Research April 2010; 9 (2): 165-171

(C) Pharmacotherapy Group,

Faculty of Pharmacy, University of Benin

Benin City, 300001 Nigeria.

All rights reserved.

Research Article

Available online at http://www.tjpr.org

\title{
Antimicrobial Activity of 23 Endemic Plants in Madagascar
}

\section{Erick Francisco Rakotoniriana ${ }^{1,2^{*}}$, Jean François Rajaonarison', Emmanuel Guy Raoelison', Jacob Philémon Rajaonarivelo', Nia Manga ${ }^{2}$, Marcellin Solofoniaina ${ }^{1}$, Benja Rakotonirina1, Denis Randriamampionona ${ }^{1}$, Christian Rabemanantsoa', Kiban Cheuk ${ }^{1}$, Suzanne Urveg- Ratsimamanga ${ }^{1}$ and Joëlle Quetin Leclercq ${ }^{2}$}

${ }^{1}$ Laboratoire de microbiologie et de standardisation des médicaments, Institut Malgache de Recherches Appliquées, BP3833, Avarabohitra, Antananarivo, Madagascar, ${ }^{2}$ Laboratoire de Pharmacognosie, Unité CHAM, Louvain Drug Research Institute, Université catholique de Louvain, 72, UCL7230, Av. E. Mounier- 1200 Bruxelles, Belgium

\begin{abstract}
Purpose: To screen the crude methanol extracts obtained from 23 endemic plants in Madagascar for antimicrobial activity.

Methods: In order to assess the antimicrobial properties of the extracts, their minimum inhibitory concentrations (MICs) were obtained using the broth microdilution method. The six test pathogenic species used were Bacillus subtilis, Staphylococcus aureus, Escherichia coli, Salmonella typhi, Pseudomonas aeruginosa and Candida albicans. Bioautography agar overlay test and phytochemical screening were also performed on the most active extracts.

Results: From the 23 plants tested, 16 of which are used in traditional medicine, Poivrea phaneropetala (Combretaceae), Koehneria madagascariensis (Lythraceae) and Rhopalopilia perrieri (Opiliaceae) exhibited the broad spectrum of activity, being active against all the test organisms, while Monoporus clusiifolius (Myrsinaceae) showed the strongest antifungal activity against Candida albicans with a minimal inhibitory concentration of 0.250 $\mathrm{mg} / \mathrm{ml}$. Bioautography and phytochemical analysis of the five active extracts against bacterial strains and of one active extract against $C$. albicans indicate that the active compounds responsible for antimicrobial activity may be mainly flavonoids and/or terpenes.

Conclusion: These preliminary results are the first antimicrobial studies on these plants and lend support for the use of some of them in traditional medicine.
\end{abstract}

Keywords: Antimicrobial properties, Traditional medicine, Microdilution assay, Bioautography, Madagascar.

*Corresponding author: E-mail: erickfrancisco_rakouth@yahoo.fr; Tel: +32496431884 


\section{INTRODUCTION}

Madagascar is host to approximately 12,000 vegetable species, more than $80 \%$ of which are endemic to the island [1]. Owing to environmental degradation, increasing deforestation, slash and burn agriculture in primary forest, this unique patrimony is threatened by extinction. Only $9 \%$ of the original areas are currently available and the country is among 25 most critical regions for plant life protection in the world [2].

In Madagascar, herbal medicines are often used as the first line of treatment of various diseases. The practice of traditional medicine is well-embedded in the lifestyle of the eighteen indigenous tribes of Madagascar. Previous investigations on Madagascan flora mainly dealt with ethnobotanical practices of plants in folk medicine [3-5]. Screening surveys have already shown some biological activities such as antiplasmodial [6], antiviral [7], and cytotoxic activities [8]. However, very few scientific studies have been carried out on the putative antimicrobial properties of endemic plants in the island although many of them have been claimed by local traditional healers to be effective in the treatment of infectious diseases.

The aim of this study was to investigate the antimicrobial properties of 23 endemic plants obtained from different parts of the country and to identify the phytochemical class of active components.

\section{EXPERIMENTAL}

\section{Plant materials}

The plants were collected from various locations in Madagascar and were authenticated by Dr Armand Rakotozafy, the curator of the Department of Botany at the Institut Malgache de Recherches Appliquées (IMRA), Antananarivo, Madagascar. Voucher specimens were deposited at the herbarium of the Parc Botanique et Zoologique de Tsimbazaza, Antananarivo, Madagascar.
Plant names and their folkoric use are given in Table 1. Dried plant materials were ground into fine powders and preserved at the IMRA herbarium.

Table 1: List of 23 Madagascan endemic plants used in the study and their folkoric use

\begin{tabular}{|c|c|c|}
\hline Family & Species name & Folkloric use \\
\hline Annonaceae & Xylopia buxifolia Baill. & $\begin{array}{l}\text { Tonic, } \\
\text { jaundice }\end{array}$ \\
\hline Apocynaceae & $\begin{array}{l}\text { Mascarenhasia } \\
\text { lisianthiflora A. DC. }\end{array}$ & n.i \\
\hline Asteraceae & Pluchea grevei Humbert & $\begin{array}{l}\text { Headache, } \\
\text { tonic }\end{array}$ \\
\hline Asteropeiaceae & $\begin{array}{l}\text { Asteropeia densiflora } \\
\text { Baker }\end{array}$ & n.i \\
\hline Celastraceae & $\begin{array}{l}\text { Evonymopsis longipes } \\
\mathrm{H} \text {. Perrier }\end{array}$ & Headache \\
\hline Clusiaceae & $\begin{array}{l}\text { Symphonia clusioides } \\
\text { Baker }\end{array}$ & Hair ointment \\
\hline Combretaceae & $\begin{array}{l}\text { Poivrea phaneropetala } \\
\text { (Baker) H. Perrier }\end{array}$ & Vermifuge \\
\hline Combretaceae & $\begin{array}{l}\text { Poivrea grandidieri } \\
\text { (Baill.) H. Perrier }\end{array}$ & $\begin{array}{l}\text { Vermifuge, } \\
\text { icterus }\end{array}$ \\
\hline Combretaceae & $\begin{array}{l}\text { Poivrea obscura (Tul.) } \\
\text { H. Perrier }\end{array}$ & $\begin{array}{l}\text { Vermifuge, } \\
\text { diuretic }\end{array}$ \\
\hline Dilleniaceae & Hibbertia coriacea Baill. & $\begin{array}{l}\text { Vaginitis, } \\
\text { urethritis }\end{array}$ \\
\hline Elaeocarpaceae & $\begin{array}{l}\text { Elaeocarpus sericeus } \\
\text { Baker }\end{array}$ & n.i \\
\hline Fabaceae & $\begin{array}{l}\text { Piptadenia pervillei } \\
\text { Vatke }\end{array}$ & Antimalarial \\
\hline Lythraceae & $\begin{array}{l}\text { Koehneria } \\
\text { madagascariensis } \\
\text { (Baker) } \\
\text { S.A.Graham, H.Tobe \& } \\
\text { P.Baas }\end{array}$ & n.i \\
\hline Melastomaceae & $\begin{array}{l}\text { Dichaetanthera } \\
\text { oblongifolia Baker }\end{array}$ & $\begin{array}{l}\text { Diarrhea, } \\
\text { dysentery }\end{array}$ \\
\hline Moraceae & $\begin{array}{l}\text { Pachytrophe dimepate } \\
\text { Bureau }\end{array}$ & Jaundice \\
\hline Myrsinaceae & $\begin{array}{l}\text { Monoporus clusiifolius } \\
\text { H. Perrier }\end{array}$ & n.i \\
\hline Opiliaceae & $\begin{array}{l}\text { Rhopalopilia perrieri } \\
\text { Cavaco \& Keraudren }\end{array}$ & $\begin{array}{l}\text { Antiseptic, } \\
\text { wound } \\
\text { healing }\end{array}$ \\
\hline Rhamnaceae & $\begin{array}{l}\text { Bathiorhamnus louvelii } \\
\text { (H. Perrier) Capuron }\end{array}$ & Purgative \\
\hline Sapindaceae & $\begin{array}{l}\text { Conchopetalum } \\
\text { madagascariense Radlk }\end{array}$ & n.i \\
\hline Sarcolaenaceae & $\begin{array}{l}\text { Leptolaena pauciflora } \\
\text { Baker }\end{array}$ & $\begin{array}{l}\text { Venereal } \\
\text { disease }\end{array}$ \\
\hline Sarcolaenaceae & $\begin{array}{l}\text { Leptolaena diospyroidea } \\
\text { (Baill.) Cavaco }\end{array}$ & $\begin{array}{l}\text { Impotence to } \\
\text { man }\end{array}$ \\
\hline Sterculiaceae & $\begin{array}{l}\text { Rulingia } \\
\text { madagascariensis Baker }\end{array}$ & n.i \\
\hline Thymelaeaceae & $\begin{array}{l}\text { Peddiea involucrata } \\
\text { Baker }\end{array}$ & Antimalarial \\
\hline
\end{tabular}

Trop J Pharm Res, April 2010; 9 (2):166 


\section{Preparation of plant extracts}

Dried and powdered plants (10 g) were macerated with agitation in $50 \mathrm{ml}$ methanol $(\mathrm{MeOH})$ overnight at room temperature. After filtration, the solvent was eliminated by evaporation at reduced pressure and crude extracts were dried at $45{ }^{\circ} \mathrm{C}$ using a speedvac concentrator (Savant), and stored at the IMRA bank at $4{ }^{\circ} \mathrm{C}$.

\section{Microorganisms}

The bacterial strains used for the investigation were Bacillus subtilis, Staphylococcus aureus, Escherichia coli, Salmonella typhi and Pseudomonas aeruginosa, and were all obtained as clinical isolates from patients at the Microbiology Department, IMRA. The yeast strain, Candida albicans (MUCL 31360), was obtained from the Mycothèque de l'Université Catholique de Louvain (MUCL), Belgium. Stock cultures were maintained at $4{ }^{\circ} \mathrm{C}$ on slopes of nutrient agar (Difco) for bacteria and on Sabouraud dextrose agar (SDA, Difco) for the yeast, prior to their use.

\section{Determination of minimum inhibitory concentration (MIC)}

The broth microdilution method was used to assess the MIC of the different plant extracts in a 96-well microplate using a modified method [9]. Microbial suspensions were first prepared from an overnight culture of bacterial and fungal cells grown in flasks, each containing $10 \mathrm{ml}$ of Mueller-Hinton Broth (Oxoid) for bacteria and Sabouraud dextrose broth (Difco) for yeast at $37^{\circ} \mathrm{C}$ and $30{ }^{\circ} \mathrm{C}$, respectively. The turbidity of the microbial suspensions was adjusted to 0.5 McFarland using Densicheck (BioMerieux). Stock solutions of the different extracts were prepared by re-suspending the crude methanol extracts in $10 \%$ dimethyl sulfoxide (DMSO) to produce concentrations in the range of $1.25-160 \mathrm{mg} / \mathrm{ml}$. These solutions were further diluted 10 -fold with water and then sterilized by filtration through $0.22 \mu \mathrm{m}$ membrane filters. A known volume $(100 \mu \mathrm{l})$ of each solution was deposited in the wells. This was followed by the addition of $100 \mu \mathrm{l}$ of the inoculum (approximately $10^{6} \mathrm{CFU} / \mathrm{ml}$ for bacteria and $10^{5} \mathrm{CFU} / \mathrm{ml}$ for $C$. albicans) was added to each well. The microplates were incubated overnight at $37{ }^{\circ} \mathrm{C}$ for bacteria and $30{ }^{\circ} \mathrm{C}$ for $48 \mathrm{~h}$ for $\mathrm{C}$. albicans. After incubation, $40 \mu \mathrm{l}$ of $0.2 \mathrm{mg} / \mathrm{ml}$ aqueous solution of methylthiazoyltetrazolium chloride (MTT) was added to each well and further incubated for $30 \mathrm{~min}$ at room temperature. MIC was defined as the lowest concentration in which no transformation of MTT was observed. Streptomycin sulfate and nystatin were used as positive controls and their MICs were determined using the same process. All samples were tested in triplicate and the tests were repeted twice.

\section{Bioautography agar-overlay assay with $B$. subtilis and $C$. albicans}

Plant extracts showing significant antimicrobial activity with MICs values close to $1 \mathrm{mg} / \mathrm{mL}$ against $B$. subtilis or $C$. albicans were investigated by thin layer chromatography (TLC) bioautographic agar-overlay according to the method of Rahalison et al [10] with minor modifications. Twenty microlitres of different solutions of the methanol plant extract $(400 \mu \mathrm{g})$ were applied to precoated Silica gel GF254 plates (Merck KGaA, Darmstadt, Germany). TLC plates were developed with ethyl acetate/methanol $1 / 1 \quad(\mathrm{v} / \mathrm{v})$ for $B$. subtilis and ethyl acetate/methanol/water $10 / 10 / 3(\mathrm{v} / \mathrm{v} / \mathrm{v})$ for $C$. albicans and dried thoroughly overnight to achieve complete removal of the solvents. The developed TLC plates were thinly overlaid with molten malt extract agar and with SDA inoculated with an overnight culture of $B$. subtilis and $C$. albicans, respectively. The plates were incubated in a dark and humid chamber at $25{ }^{\circ} \mathrm{C}$ for $24 \mathrm{~h}$ for $B$. subtilis and $48 \mathrm{~h}$ for $C$. albicans. After incubation, cultures were sprayed with MTT and further incubated for $30 \mathrm{~min}$ at room temperature. Microbial growth inhibition appeared as clear zones around active 
compounds against a purple background. The plates were in duplicate. One set was used for bioautography experiment and the other was intended for the reference chromatogram. The experiments were repeated twice.

\section{Phytochemical screening}

Plant extracts previously selected for TLC bioautographic assays were subjected to preliminary phytochemical screening to determine the major chemical groups corresponding to active compounds responsible for the observed inhibition zones. TLC was first developed with the same solvent systems as previously mentioned above. For the detection of alkaloid, coumarins, flavonoids and terpenes, phytochemical screening was performed using standard procedures [11]. Observations were made from two independent experiments.

\section{RESULTS}

A total of 23 methanol plant extracts of Madagascan endemic species belonging to 20 different botanical families, among which 16 are used in traditional medicine (Table 1), were tested for their antimicrobial activities against 5 bacterial species and one yeast. The results of these tests are summarized in Table 2. Eight extracts inhibited the growth of $B$. subtilis at MIC values lower or equal to 1 $\mathrm{mg} / \mathrm{ml}$. Among them, the extract of Rhopalopilia perrieri Cavaco \& Keraudren (Opiliaceae) exhibited the lowest MIC value $(0.13 \mathrm{mg} / \mathrm{ml})$. Four of them were also found to be effective against $S$. aureus at $1 \mathrm{mg} / \mathrm{ml}$. Five extracts were moderately active against $E$. coli and $S$. typhi with MIC values ranging from 2 to $4 \mathrm{mg} / \mathrm{ml}$. None of the tested plant extracts displayed activity against $P$. aeruginosa (MIC > $8 \mathrm{mg} / \mathrm{ml}$ ) except Poivrea phaneropetala (Baker) $\mathrm{H}$. Perrier (Combretaceae), Koehneria madagascariensis (Baker) S.A.Graham, H.Tobe and P.Baas (Lythraceae) and R. perrieri. Of the 6 plant extracts that inhibited $C$. albicans at
MIC lower or equal to $2 \mathrm{mg} / \mathrm{ml}$, Monoporus clusiifolius $\mathrm{H}$. Perrier (Myrsinaceae) showed the most interesting inhibitory activity against C. albicans with a MIC of $0.25 \mathrm{mg} / \mathrm{ml}$

\section{DISCUSSION}

This study showed that all but two plant extracts possessed some degree of activity against at least one tested microorganism, at the highest tested dose of $8 \mathrm{mg} / \mathrm{ml}$. Overall, Gram positive bacteria (B.subtilis and $S$. aureus) were more sensitive to plant extracts than Gram negative bacteria (E. coli, S. typhi and P.aeruginosa). Among them, $P$. phaneropetala, K. madagascariensis and $R$. perrieri demonstrated a broad spectrum of activity against all the tested organisms while $M$. clusiifolius was the most active against $C$. albicans. $R$. perrieri showed the most promising antibacterial activity, confirming its use in traditional medicine as antiseptic and wound healing. The present investigation also confirmed the anti-infective property of $H$. coriacea in the treatment of vaginitis and urethritis and that of $D$. oblongifolia which is used to treat diarrhoea and dysentery in folk medicine. In contrast, the use of Leptolaena pauciflora Baker (Sarcolaenaceae) as antiinfective agent for the treatment of venereal diseases was not supported by our investigation. Furthermore, the oral use of this plant containing several phenolic compounds could be toxic [12].

Based on this investigation, we are unable to say categorically that extracts having the same Rf values contained the same bioactive compounds. It is possible that the observed inhibition was likely due to one or more compounds sharing the same $\mathrm{Rf}$ in the solvent system used, particularly for low Rf spots. Preliminary phytochemical screening revealed the presence of flavonoids, alkaloids and terpenes as the probable active compounds present in the crude extracts. It is well known that numerous members of these phytochemical groups have already demonstrated antimicrobial activity [13]. 
Table 2: Antimicrobial activity of 23 Madagascan endemic plants

\begin{tabular}{|c|c|c|c|c|c|c|c|}
\hline \multirow[t]{2}{*}{ Plant } & \multirow[t]{2}{*}{ Voucher no. } & \multicolumn{6}{|c|}{ Microorganisms ${ }^{\mathrm{a}} / \mathrm{MIC}^{\mathrm{b}}(\mathrm{mg} / \mathrm{ml})$} \\
\hline & & B.s & S.a & E.c & S.t & P.a & C.a \\
\hline Xylopia buxifolia & AML6 & - & - & - & - & - & - \\
\hline Mascarenhasia lisianthiflora & MOR23 & 2 & - & - & - & - & - \\
\hline Pluchea grevei & TUL16 & 4 & - & - & - & - & 4 \\
\hline Asteropeia densiflora & TUL8 & 0.5 & 2 & - & - & - & 2 \\
\hline Evonymopsis longipes & MOR33 & 2 & 8 & - & - & - & 8 \\
\hline Symphonia clusioides & AMB34 & - & - & - & - & - & - \\
\hline Poivrea phaneropetala & MOR12 & 0.5 & 1 & 4 & 4 & 8 & 2 \\
\hline Poivrea grandidieri & TUL10 & 4 & 8 & 8 & 8 & - & 8 \\
\hline Poivrea obscura & MOR26 & 1 & 1 & 4 & 4 & - & - \\
\hline Hibbertia coriacea & MKR44 & 1 & 2 & 4 & 2 & - & 4 \\
\hline Elaeocarpus sericeus & M447 & 1 & 4 & - & - & - & 4 \\
\hline Piptadenia pervillei & AA17 & 2 & 8 & 8 & 8 & - & - \\
\hline Koehneria madagascariensis & TUL5 & 0.5 & 1 & 4 & 4 & 8 & 2 \\
\hline Dichaetanthera oblongifolia & BP31 & 1 & 2 & - & - & - & 2 \\
\hline Pachytrophe dimepate & VAM282 & 2 & - & - & - & - & - \\
\hline Monoporus clusiifolius & AMB43 & 2 & 8 & - & - & - & 0.25 \\
\hline Rhopalopilia perrieri & TUL35 & 0.13 & 1 & 4 & 4 & 8 & 2 \\
\hline Bathiorhamnus louvelii & AA68 & 2 & - & - & - & - & - \\
\hline Conchopetalum madagascariense & VAT652 & 2 & - & - & - & - & - \\
\hline Leptolaena pauciflora & MKR692 & 4 & 8 & 8 & 8 & - & 8 \\
\hline Leptolaena diospyroidea & MOR56 & 4 & - & - & - & - & - \\
\hline Rulingia madagascariensis & BP14 & 4 & 8 & - & - & - & 8 \\
\hline Peddiea involucrata & AA48 & 4 & 8 & - & - & - & - \\
\hline \multicolumn{8}{|l|}{ References $(\mu \mathrm{g} / \mathrm{ml})$} \\
\hline Streptomycine & & 3.9 & 3.9 & 31.3 & 31.3 & - & nd \\
\hline Nystatine & & nd & nd & nd & nd & nd & 3.13 \\
\hline
\end{tabular}

${ }^{a}$ MIC: minimal inhibitory concentration $(\mathrm{mg} / \mathrm{ml})$

${ }^{b}$ Microorganisms: B.s = Bacillus subtilis; S.a = Staphylococcus aureus; E.c = Escherichia coli; S.t = Salmonella typhi; P.s = Pseudomonas aeruginosa; C.a = Candida albicans (-): MIC > $8 \mathrm{mg} / \mathrm{ml}$ for plant extracts and MIC $>64 \mu \mathrm{g} / \mathrm{ml}$ for streptomycin; nd = not determined

Overall, five plant extracts with MICs lower than $1 \mathrm{mg} / \mathrm{ml}$ against either B. subtilis or C. albicans were subjected to TLC bioautographic agar overlay test. Rf value of the inhibition zones and the probable chemical group of compound responsible for the inhibition are listed in Table 3. The tests based on colour development suggested that the active compounds belong mainly to flavonoid or terpene groups. Furthermore, a positive test with Dragendorf reagent suggests that Asteropeia densiflora Baker (Asteropeiaceae) and R. perrieri may contain alkaloids at Rf of 0.02 (at base line).

Table 3: Phytochemical screening of active compounds responsible for microbial inhibition based on bioautography assays

\begin{tabular}{llllll}
\hline Plant & \multicolumn{6}{c}{ Rf } & \multicolumn{3}{c}{ Phytocompound $^{\mathrm{a}}$} \\
& value & A & C & F & Te \\
\hline Monoporus clusiifoliuss $^{\mathrm{b}}$ & 0.68 & - & - & + & + \\
Poivrea phaneropetala $^{\mathrm{c}}$ & 0.1 & - & - & + & + \\
Koehneria madagascariensis $^{\mathrm{c}}$ & 0.1 & - & - & + & + \\
Asteropeia densiflora $^{\mathrm{c}}$ & 0.02 & + & - & + & + \\
Rhopalopilia perrieri $^{\mathrm{c}}$ & 0.75 & - & - & + & + \\
\hline
\end{tabular}

\footnotetext{
${ }^{a} A=$ Alkaloids; $C=$ Coumarins; F= Flavonoids; $T e=$ Terpenes

${ }^{b}$ Test performed on TLC bioautographic agar-overlay with solvent system EtOAc/MeOH/H $\mathrm{H}_{2} \mathrm{O}(10 / 10 / 3)$ using C. albicans as organism test

${ }^{c}$ Test performed on TLC biautographic agar-overlay with solvent system EtOAC/MeOH (1/1) using B. subtilis as organism test
} 
In many cases, these substances serve as plant defense mechanisms against aggression by microorganisms, insects, and herbivores either synthesized during the plant normal development (constitutive resistance factors) or induced only after contact with the pathogen (induced resistance factor) [14].

To the best of our knowledge, no previous antimicrobial survey has been reported on these plants. However, some of them were previously reported for other biological activities. Literature searches indicate that Evonymopsis longipes $(\mathrm{H}$. Perrier) $\mathrm{H}$. Perrier (Celastraceae) was particularly potent and could completely inactivate the Herpes Simplex Virus at a concentration lower than $25 \mu \mathrm{g} / \mathrm{ml}$ [7]. Peddiea involucrata Baker (Thymelaeaceae) and Piptadenia pervillei Vatke (Fabaceae) were said to possess antimalarial activity [15-16]. From this latter was isolated (+)-catechin 5-gallate and (+)catechin 3-gallate which demonstrated, in vitro, high activity against the chloroquineresistant strain FcB1 of Plasmodium falciparum as well as (+)-catechinant ethylgallate which were less effective [16]. With regard to antibacterial activity, howerver, these plants were less effective, being active only against $B$. subtilis with MIC ranging from 2 to $4 \mathrm{mg} / \mathrm{ml}$.

While no ethnomedicinal practices were reported to date for 7 of the 23 plants, the study revealed that $A$. densiflora and $K$. madagascariensis were found to possess effective antibacterial activity; in addition, the extract from $M$. clusiifolius may be a good candidate in the search for potential antifungal compounds. Further stuydies on these plants are being undertaken in our laboratory to isolate and elucidate the compounds responsible for the observed anti-candidiasis and antibacterial activities.

\section{CONCLUSION}

This survey contributes new data to the existing knowledge of antimicrobial activity of the endemic flora of Madagascar and may serve as a basis for further pharmaceutical investigation. The findings also lend support for the use of some of these plants in traditional medicine in Madagascar.

\section{ACKNOWLEDGMENT}

The authors are grateful to the Coopération Universitaire Belge pour le Développement (CUD) for financial support which enabled this survey to be carried and a grant to $\mathrm{N}$. Manga. We wish to thank Prof. Philippe Rasoanaivo for helpful comments on the manuscript.

\section{REFERENCES}

1. Robinson JG. An island of evolutionary exuberance. Science, 2004; 304 (5667): 53.

2. Myers $N$, Mittermeier RA, Mittermeier CG, Da Fonseca GAB, Kent J. Biodiversity hotspots for conservation priorities. Nature, 2000; 403: 853-858.

3. Beaujard P. Plants and traditional medicine in Southeast Madagascar. J Ethnopharmacol, 1988; 23: 165-265.

4. Novy JW. Medicinal plants of the eastern region of Madagascar. J Ethnopharmacol, 1997; 55: 119-226.

5. Norscia I, Borgognini-Tarli SM. Ethnobotanical reputation of plant species from two forests of Madagascar: a preliminary investigation. S Afr J Bot, 2006; 72 (4): 656-660.

6. Rasoanaivo $P$, Ramanitrahasimbola $D$, Rafatro $H$, Rakotondramanana $D$, Robijaona $B$, Rakotozafy A, Ratsimamanga-Urveg $S$, Labaied M, Grellier $P$, Allorge $L$ et al. Screening extracts of Madagascan plants in search of antiplasmodial compounds. Phytother Res, 2004; 18(9): 742-747.

7. Hudson JB, Lee MK, Rasoanaivo P. Antiviral activities in plants endemic to Madagascar. Pharmaceut Biol, 2000; 38 (1): 36-39.

8. Williams RB, Norris A, Miller JS, Razafitsalama LJ, Andriantsiferana $R$, Rasamison VE, Kingston DG. Two new cytotoxic naphthoquinones from Mendoncia cowanii from the rainforest of Madagascar. Planta Med, 2006; 72: 564-566.

9. Eloff JN. A sensitive and quick microplate method to determine the minimal inhibitory concentration of plant extracts for bacteria. Planta Med, 1998; 64: 711-713.

10. Rahalison L, Hamburger $M$, Hostettmann $K$, Monod M, Frenk E. A bioautographic agar overlay method for the detection of 
Rakotoniriana et al

antifungal compounds from higher plants. Phytochem Anal, 1991; 2:199-203.

11. Wagner $H$, Bladt S. Plant drug analysis. A thin layer chromatography atlas. SpringerVerlag, Berlin Heidelberg; 1996.384p.

12. Paris $R$, Jacquemin $H$, Linard $A$. Madagascar plants. XV. Chlaenaceae from Malagasy. Leptolaena pauciflora, L. diospyroidea cavaco var tampoketsensis, and Sarcolaena multiflora. Presence of myricetol heterosides. Plantes Méd et Phyto, 1975; 9: 230-237.

13. Cowan MM. Plant products as antimicrobial agents. Clin Microbiol Rev, 1999; 12 (4): 564-582.
14. Castro MS, Fontes W. Plant defense and antimicrobial peptides. Protein Pept Lett, 2005; 12: 11-16.

15. Randrianarivelojosia $M$, Rasidimanana $V T$, Rabarison H, Cheplogoi PK, Ratsimbason M, Mulholland DA, Mauclere P.. Plants traditionally prescribed to treat tazo (malaria) in the eastern region of Madagascar. Malar J, 2003; 2: 25.

16. Ramanandraibe V, Grellier $P$, Martin MT, Deville A, Joyeau $R$, Ramanitrahasimbola $D$, Mouray E, Rasoanaivo $P, \quad M a m b u \quad L$. Antiplasmodial phenolic compounds from Piptadenia pervillei. Planta Medica, 2008; 74: 417-421. 